\title{
Effects of ovine conceptus secretory proteins and progesterone on oxytocin-stimulated endometrial production of prostaglandin and turnover of inositol phosphate in ovariectomized ewes
}

\author{
T. L. Ott, M. A. Mirando*, M. A. Davis and F. W. Bazer \\ Animal Science Department, University of Florida, Gainesville, FL 32611, USA
}

\begin{abstract}
Summary. This study examined the effects of progesterone and intrauterine injection of ovine conceptus secretory proteins (oCSP) on endometrial responsiveness to oxytocin. Twelve ewes were ovariectomized on day 4 of the cycle (oestrus $=$ day 0 ) and assigned in a $2 \times 2$ factorial arrangement, to receive either $1.5 \mathrm{mg}$ ovine serum proteins (SP) or oCSP containing $25 \mu \mathrm{g}$ ovine trophoblast protein 1 (oTP-1) (by radioimmunoassay) in $1.5 \mathrm{mg}$ total protein into each uterine horn, via catheters, twice a day on days $11,12,13$ and 14 . Ewes received $200 \mathrm{mg}$ progesterone per day (i.m.) from day 4 to day 10 or 15 . Oxytocin-induced prostaglandin $F_{2 \alpha}$ was measured as 13,14dihydro-15-keto-prostaglandin $\mathrm{F}_{2 a}$ (PGFM) on days $11,12,13$ and 14 in plasma from three integrated, $10 \mathrm{~min}(10 \mathrm{ml})$ blood samples $(0-10,10-20,20-30 \mathrm{~min})$ obtained after intravenous injection of $20 \mathrm{iu}$ oxytocin, and in a pre-oxytocin $(-10$ to $0 \mathrm{~min}$ ) sample collected via an indwelling jugular catheter. The pre-oxytocin samples were also assayed for progesterone. Oxytocin-induced turnover of inositol phosphate was determined in endometrium on day 15 after hysterectomy. In ewes receiving progesterone to day 10 , plasma progesterone decreased from about 12 to $2 \mathrm{ng} \mathrm{ml}^{-1}$ (SEM $\pm 2 \cdot 6$ ) during the treatment period (days 11-14), but remained high $\left(12-20 \pm 2 \cdot 6 \mathrm{ng} \mathrm{ml}^{-1}\right)$ in ewes that received progesterone to day 15 . Intrauterine injection of oCSP resulted in high basal concentrations of PGFM on days 12 and 13 compared with SP-treated ewes $(P<0.01)$. Treatments with progesterone did not affect basal PGFM concentrations. Treatment with oCSP abolished oxytocin-induced endometrial secretion of prostaglandin only if progesterone was maintained to day 15 $(P<0.01)$; in ewes receiving such treatment, oCSP inhibited $(P<0.01)$, but SP did not inhibit, oxytocin-induced endometrial turnover of inositol phosphate $(P<0.06)$, which was greater in ewes treated with progesterone to day 10 than in those treated to day $15(P<0 \cdot 05)$. Ewes that responded to oxytocin with increased PGFM exhibited increased oxytocin-stimulated turnover of inositol phosphate on day 15. These results indicate that the antiluteolytic action oTP-1 exerts on the endometrium requires progesterone and that this mechanism involves inhibition of oxytocin-stimulated turnover of inositol phosphate.
\end{abstract}

Keywords: sheep; conceptus; prostaglandin $\mathrm{F}_{2 a}$; progesterone; oxytocin

*Present address: Department of Animal Sciences, Washington State University, Pullman, WA 99164, USA. 


\section{Introduction}

Establishment of pregnancy in ewes requires the presence of a conceptus in the uterus by days 12-13 of the oestrous cycle (Moor \& Rowson, 1966a, b). A conceptus secretory protein, initially identified as trophoblastin (Martal et al., 1979), later characterized and named ovine trophoblast protein-1 (oTP-1; Godkin et al., 1982, 1984), is thought to be primarily responsible for the anti-luteolytic effects of the ovine conceptus (see Bazer et al., 1989, 1991). oTP-1 is a type I trophoblast interferon secreted by sheep conceptuses between days 10 and 21 of pregnancy (Bazer et al., 1986; Imakawa et al., 1987; Stewart et al., 1987). Vallet et al. (1988b) demonstrated that purified oTP-1 or oCSP extend the interoestrus interval to a similar extent when injected into the uterine lumen on days 12-14 of the oestrous cycle. However, oCSP from which oTP-1 was removed did not extend the interoestrus interval when compared with control ewes treated with serum protein. The mechanism by which oTP-1 extends corpus luteum function remains to be defined.

The endometrium of cyclic ewes releases pulses of prostaglandin $\mathrm{F}_{2 a}\left(\mathrm{PGF}_{2 a}\right)$ into the uterine vein on days 14-17 (McCracken et al., 1971; Thorburn et al., 1972; Zarco et al., 1988). Pulsatile secretion of uterine $\mathrm{PGF}_{2 a}$ is thought to be responsible for luteolysis, since continuous infusion of, or immunization against, $\mathrm{PGF}_{2 \alpha}$ results in extension of the cycle (Scaramuzzi \& Baird, 1976; Fairclough et al., 1981). Pulsatile release of oxytocin from the ovary, neurohypophysis or from both is thought to be responsible for pulsatile secretion of $\mathrm{PGF}_{2 a}$ from the endometrium, since $>95 \%$ of all pulses of $\mathrm{PGF}_{2 a}$ occur at the same time as pulses of oxytocin (Flint \& Sheldrick, 1986; Hooper et al., 1986). Secretion of oxytocin is similar in cyclic and pregnant ewes during maternal recognition of pregnancy and parallels the rise and fall of progesterone secretion by the corpus luteum (Flint \& Sheldrick, 1986; Hooper et al., 1986; Rhodes \& Nathanielsz, 1990). Concentrations of endometrial oxytocin receptor are high during luteolysis, but are greatly reduced in pregnant ewes (Roberts et al., 1976; McCracken et al., 1984; Sheldrick \& Flint, 1985). Pulsatile secretion of $\mathrm{PGF}_{2 a}$ by the uterus is also reduced during the period of maternal recognition of pregnancy (Hooper et al., 1986; Zarco et al., 1988). Oxytocin-stimulated endometrial secretion of PGF $_{2 \alpha}$ is thought to be mediated by the inositol trisphosphate and diacylglycerol second-messenger system (Flint et al., 1986; Hixon \& Flint, 1987; Mirando et al., 1990).

Progesterone downregulates oestrogen and progesterone receptors (Evans \& Leavitt, 1980; Okulicz et al., 1981; Leavitt et al., 1985) and is thought to keep the endometrium unresponsive to oestrogen during dioestrus (McCracken et al., 1984). In pregnant ewes, conceptus secretory proteins are responsible, directly or indirectly, for generating an antiluteolytic signal to inhibit pulsatile release of uterine $\mathrm{PGF}_{2 \alpha}$, thus ensuring continued progesterone production by the corpus luteum, and for maintaining uterine responsiveness to progesterone. This study examined the interaction between oCSP and progesterone in development of oxytocin-induced uterine production of prostaglandin and turnover of inositol phosphate in ovariectomized ewes.

\section{Materials and Methods}

\section{Animals}

Mature ewes of primarily Rambouillet breeding were observed daily for oestrous behaviour using vasectomized rams. Twelve ewes, having exhibited at least two oestrous cycles of normal length, were assigned randomly, at standing oestrus, to a treatment group. On day 4 , bilateral uterine catheterization and ovariectomy were performed in supine ewes under halothane anaesthesia (Fincher et al., 1986). Ewes were fitted with indwelling jugular catheters on day 10 and housed individually in crates for the remainder of the experiment.

\section{Preparation of proteins}

Pregnant ewes were laparotomized 16 days after mating, and conceptuses were collected and cultured as described by Godkin et al. (1982). Concentration of oTP-1 was determined by radioimmunoassay (Vallet et al., 1988a) and 
oCSP was diluted with sterile $0.9 \% \mathrm{NaCl}$ to an oTP-1 concentration of $25 \mu \mathrm{g} \mathrm{ml}^{-1}$. Concentration of total protein in oCSP after dilution was $0.75 \mathrm{mg} \mathrm{ml}^{-1}$ (Lowry et al., 1951). Aliquants of oCSP $(1.0 \mathrm{ml})$ were stored at $-20^{\circ} \mathrm{C}$.

For preparation of serum proteins (SP), blood was collected from the jugular vein of a pregnant ewe on day 16 after mating and allowed to clot at room temperature (for $1 \mathrm{~h}$ ) and then at $4^{\circ} \mathrm{C}$ (overnight). Serum was diluted with sterile $0.9 \% \mathrm{NaCl}$ to protein concentrations of either 1.5 or $7.5 \mathrm{mg} \mathrm{ml}^{-1}$, divided into 1.0 or $0.1 \mathrm{ml}$ aliquants, respectively, and stored at $-20^{\circ} \mathrm{C}$.

\section{Treatments}

Twelve ewes were allotted randomly in a $2 \times 2$ factorial arrangement to receive intrauterine injections of oCSP or SP on days $11,12,13$ and 14 and intramuscular injection of progesterone $\left(200 \mathrm{mg} \mathrm{day}^{-1}\right)$ from day 4 to day 10 or 15. A total of $1.5 \mathrm{mg}$ protein was injected into each uterine horn twice a day $(07: 00$ and $17: 30 \mathrm{~h})$. Progesterone injections were given after the treatment at $17: 30 \mathrm{~h}$ each day. Protein treatments were followed by $50 \mathrm{mg}$ ampicillin in $0.1 \mathrm{ml}$ saline and $1.0 \mathrm{ml}$ of $0.9 \%$ saline to clear the cathether. Before injection with oCSP, $0.75 \mathrm{mg} \mathrm{SP}(0.1 \mathrm{ml})$ was added to bring total protein to $1.5 \mathrm{mg}(1.1 \mathrm{ml})$. The $S P(1.5 \mathrm{mg})$ was in a total volume of $1.0 \mathrm{ml}$. After protein treatments at $07: 00 \mathrm{~h}$ on days 11-14, ewes were challenged with 20 iu oxytocin i.v. to stimulate maximally the available oxytocin receptors. Integrated blood samples $(10 \mathrm{ml}$ in $10 \mathrm{~min}$ ) were collected using a Harvard pump apparatus (Harvard Apparatus Co., Dover, MA, USA). Oxytocin was injected into the jugular vein via an indwelling catheter after collection of a pretreatment sample ( -10 to $0 \mathrm{~min})$, and three additional samples were collected $(0-10,10-20$ and 20 $30 \mathrm{~min}$ ). Approximately $1 \mathrm{ml}$ heparinized $\left(200 \mathrm{iu} \mathrm{m}^{-1}\right) 0.9 \% \mathrm{NaCl}$ flushed into the catheters between each sample prevented blood from clotting. Samples were stored on ice and centrifuged within $90 \mathrm{~min}$ of collection at $1800 \mathrm{~g}$ and $4^{\circ} \mathrm{C}$ for $10 \mathrm{~min}$. The plasma collected was stored at $-20^{\circ} \mathrm{C}$ until assayed for PGFM and progesterone.

\section{Turnover of inositol phosphate}

Turnover of oxytocin-stimulated inositol phosphate was determined as described by Mirando et al. (1990) in duplicate incubations of $100 \mathrm{mg}$ endometrium from each ewe. Care was taken to include similar amounts of caruncular and intercaruncular endometrium in each incubation. Incubations from each ewe were treated with 0 or $100 \mathrm{nmol}$ oxytocin $\mathbf{1}^{-1}$ (Mirando et al., 1990).

\section{Progesterone}

Concentration of progesterone, in $200 \mu \mathrm{l}$ plasma obtained before the oxytocin challenge $(07: 00 \mathrm{~h})$ on days 11-14, was determined by radioimmunoassay (Mirando et al., 1990). Average extraction efficiency was $84.8 \%$. Assay sensitivity was $10 \mathrm{pg}$ per tube and the intra- and interassay coefficients of variation were 6.2 and $9.5 \%$, respectively.

\section{Prostaglandin}

Oxytocin-stimulated uterine production of $\mathrm{PGF}_{2 a}$ was determined by measuring its stable metabolite, 13,14dihydro-15-keto-prostaglandin $\mathrm{F}_{2 a}(\mathrm{PGFM})$ in $200 \mu \mathrm{l}$ plasma collected from the jugular vein (Fincher et al, 1986). Assay sensitivity was $10 \mathrm{pg}$ per tube and intra- and interassay coefficients of variation were $3 \cdot 1$ and $8.4 \%$, respectively. Basal PGFM concentration in plasma was estimated from the pre-oxytocin-challenge blood sample $(-10$ to $0 \mathrm{~min})$. This value was subtracted from oxytocin-stimulated PGFM concentration for each ewe on each day.

\section{Statistical analyses}

Data were subjected to least-squares analysis of variance using the General Linear Models procedure of the Statistical Analysis System (SAS, 1982). For analysis of turnover of inositol phosphate, data were analysed untransformed and then log-transformed to alleviate possible heterogeneity of error variance (Snedecor \& Cochran, 1980). Split-plot analyses of variance for a $2 \times 2$ factorial arrangement were performed with protein and progesterone treatments as main effects and ewe nested within protein $\times$ progesterone treatment for PGFM, progesterone and turnover of inositol phosphate. Split-plot analysis of variance was performed on basal PGFM concentration with main effects of treatment (oCSP versus SP) and day (11,12, 13 and 14). Ewes were nested within treatment, and day was cross-classified with treatment. All tests of hypotheses were performed using the appropriate error terms according to expectation of the mean squares (Snedecor \& Cochran, 1980). Data presented are least-square means.

\section{Results}

All ewes had similar concentrations of progesterone in plasma on the day protein infusions commenced (Fig. 1). In ewes receiving progesterone to day 10, plasma concentrations of progesterone 
decreased from day 11 to day $14(P<0.01)$ and were not affected by protein treatment $(P>0 \cdot 1)$. Plasma progesterone remained high and was not affected by protein treatment in ewes receiving progesterone to day $15(P=0.52)$.

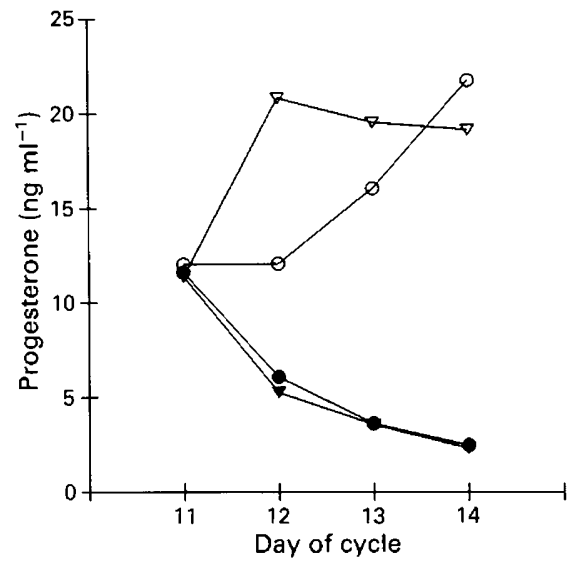

Fig. 1. Concentrations of progesterone in plasma (mean $\pm 2.6 \mathrm{ng} \mathrm{ml}^{-1}$ ) on days $11-14$ of the cycle in ovariectomized ewes receiving $200 \mathrm{mg}$ progesterone (i.m.) from day 4 to day 10 (filled symbols), or from day 4 to day 15 (open symbols), and intrauterine injections twice a day of oCSP $(\nabla$ and $\nabla)$ or SP ( $O$ and 0 ) from day 11 to day 14.

No effect of progesterone treatment on basal PGFM concentration was detected $(P>0 \cdot 1)$; data were therefore pooled within protein treatment (Fig. 2). Across protein treatments, basal PGFM varied from day 11 to day $14(P<0.01)$. In addition, a treatment $\times$ day interaction was detected $(P<0.01)$ and reflects the higher basal PGFM for oCSP-treated ewes on days 12 and 13 compared with SP-treated ewes.

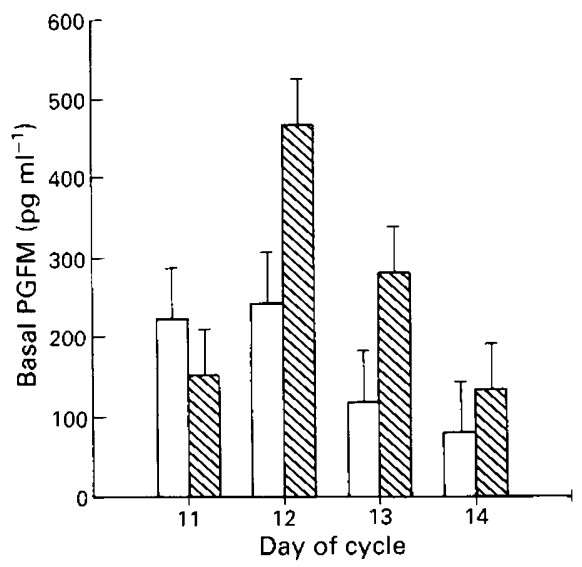

Fig. 2. Basal concentrations of 13,14-dihydro-15-keto-prostaglandin $F_{2} \alpha$ (PGFM) (mean \pm SEM) in plasma for ewes treated with serum proteins $(n=6, \square)$ or ovine conceptus secretory proteins $(n=6, \mathbb{Q})$ on days 11-14 of the cycle. No effect of progesterone treatment was detected $(P>0 \cdot 1)$. Ovine conceptus secretory protein treatment resulted in increased basal concentrations of PGFM on days 12 and $13(P=0 \cdot 07)$. 
Oxytocin-induced production of $\mathrm{PGF}_{2 \alpha}$ (plasma PGFM) is shown for ewes receiving oCSP (Fig. 3) or SP (Fig. 4). One ewe in the SP group receiving progesterone to day 15 was considered an outlier because the endometrium was secreting luteolytic amounts of $\mathrm{PGF}_{2 \alpha}$ at the beginning of the period of protein infusion (day 11) and was, therefore, removed from the data set.

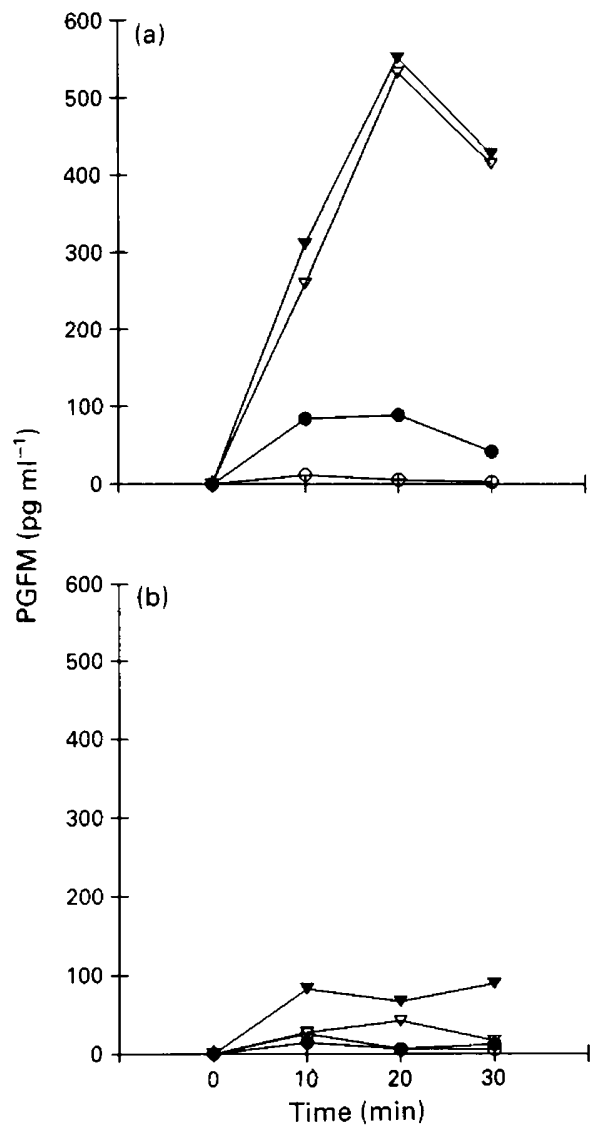

Fig. 3. Concentrations of 13,14-dihydro-15-keto-prostaglandin $F_{2 \alpha}$ (PGFM, mean $\pm 53 \cdot 5 \mathrm{pg}$ $\left.\mathrm{ml}^{-1}\right)$ in plasma in response to oxytocin $(20 \mathrm{iu})$ for ewes treated with ovine conceptus secretory proteins and receiving progesterone to (a) day 10 or (b) day 15 , on days $11(\bigcirc), 12(\bullet), 13(\nabla)$ and $14(\boldsymbol{\nabla})$ adjusted for basal PGFM concentrations for each ewe on each day. Effects of progesterone $(P<0.01)$ and protein $\times$ progesterone interaction $(P=0.07)$ were detected.

Intrauterine injection of oCSP abolished oxytocin-induced $\mathrm{PGF}_{2 a}$ in ewes receiving progesterone to day $15(P<0.01)$, but oCSP did not inhibit oxytocin-induced PGF secretion if progesterone administration was stopped on day $10(P>0 \cdot 1)$. In ewes receiving progesterone to day 10 , oCSP treatment resulted in earlier development of oxytocin-induced PGF secretion than in those receiving SP (treatment $\times$ day, $P=0 \cdot 07$ ). Ewes receiving progesterone to day 10 and $\mathrm{SP}$ treatment exhibited a pattern of PGF release similar to that expected in cyclic ewes before luteolysis. Ewes that received progesterone to day 15 and SP treatment did not demonstrate oxytocin-induced increases in PGFM by day $14(P>0 \cdot 1)$.

Analysis of log-transformed data for oxytocin-induced turnover of inositol trisphosphate and total inositol phosphate (mono, bis and trisphosphate) in endometrium yielded similar 


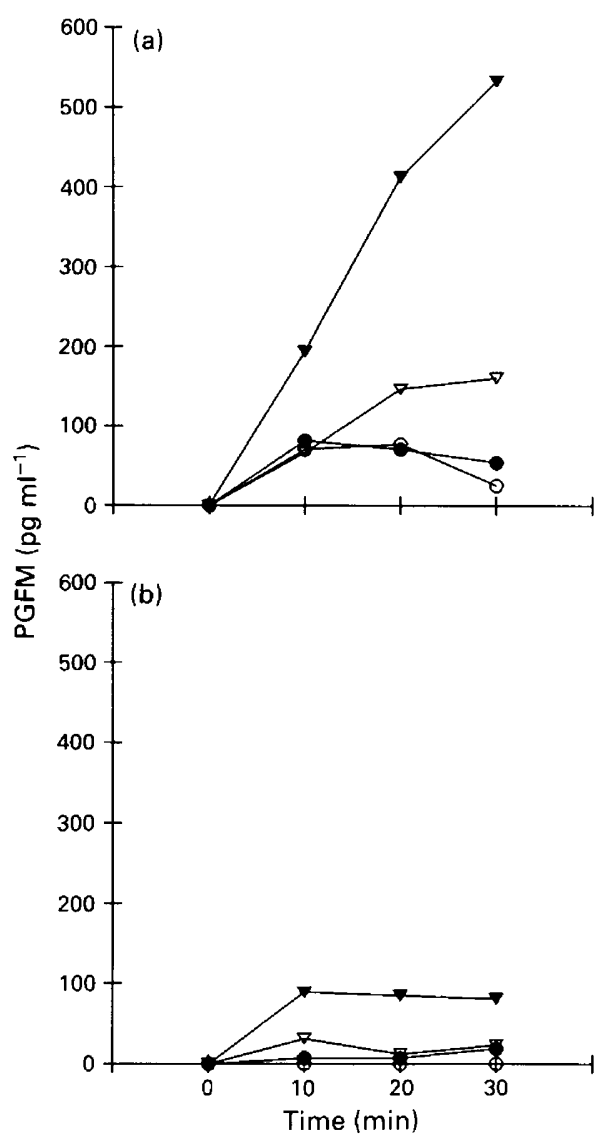

Fig. 4. Concentrations of 13,14-dihydro-15-keto-prostaglandin $F_{2 \alpha}$ (PGFM, mean) in plasma in response to oxytocin $(20 \mathrm{iu})$ for ewes treated with serum proteins and receiving progesterone to (a) day $10(\mathrm{SEM}=53.5)$ or $(\mathrm{b})$ day $15(\mathrm{SEM}=65 \cdot 5)$, on days $11(\mathrm{O}), 12(\bullet), 13(\nabla)$ and 14 $(\boldsymbol{\nabla})$ adjusted for basal PGFM secretion for each ewe on each day. Effects of progesterone $(P<0.01)$ and protein $\times$ progesterone interaction $(P=0.07)$ were detected.

conclusions; therefore, only data for total inositol phosphate are presented (Fig. 5). In ewes receiving progesterone to day 15 and oCSP, turnover was not detected; in ewes receiving progesterone to day 15 and SP, oxytocin treatment on day 15 resulted in an approximate doubling of inositol phosphate turnover compared with controls (Fig. 5; treatment $\times$ oxytocin, $P=0.08$ ). Endometrial turnover of inositol phosphate was greater in ewes receiving progesterone to day 10 than in those treated to day $15(P=0 \cdot 06)$, regardless of protein treatment.

\section{Discussion}

Maternal recognition of pregnancy in sheep may be accomplished through luteoprotective (Mapletoft et al., 1976; Henderson et al., 1977; Pratt et al., 1977; Ellinwood et al., 1979; Silvia et al., 1984) and antiluteolytic (see Bazer et al., 1989, 1991) effects of the ovine conceptus. This study focused on the antiluteolytic action of the conceptus. The interaction between conceptus secretory proteins and progesterone was examined to determine the local effects of oCSP on development of uterine responsiveness to oxytocin-stimulated $\mathrm{PGF}_{2 \alpha}$ and turnover of inositol phosphate. This 


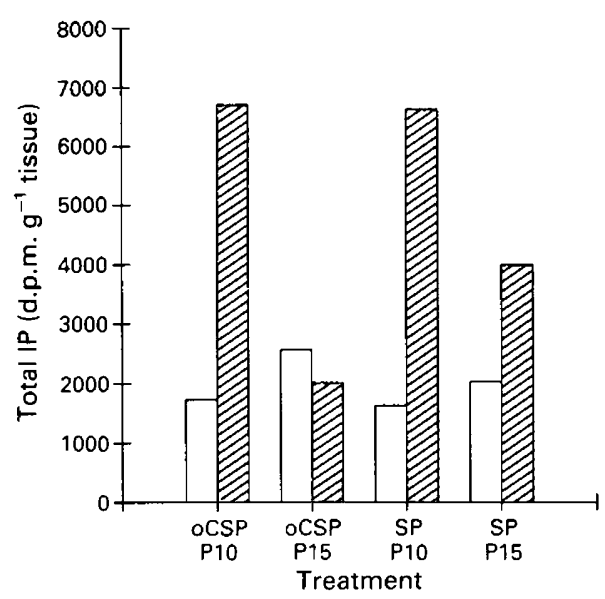

Fig. 5. Turnover of total inositol phosphate (mono, bis, and trisphosphate; d.p.m. $\mathbf{g}^{-1}$ wet weight endometrium) in response to $0(\square)$ or $100(\mathbb{G})$ nmol oxytocin $1^{-1}$ in vitro on day 15 for ewes treated with ovine conceptus secretory proteins (oCSP) or serum proteins (SP) and receiving progesterone to day 10 (P10) or day 15 (P15) of the cycle. Effects of progesterone $(P<0.01)$ and protein $\times$ oxytocin interaction $(P=0.08)$ were detected.

experiment allowed examination of the effect of conceptus secretory proteins on development of endometrial responsiveness to oxytocin during declining (progesterone to day 10) or maintained (progesterone to day 15) plasma progesterone. The former situation reflects one aspect of pregnancy failure and the latter reflects the physiology of early pregnancy.

These results clearly demonstrate that progesterone in plasma must be maintained at concentrations characteristic of dioestrus for oCSP to inhibit oxytocin-induced turnover of inositol phosphate and production of $\mathrm{PGF}_{2 \alpha}$. Maintaining adequate concentrations of progesterone in plasma in the absence of ovaries in ewes treated with serum protein effectively extended the period during which the endometrium remained unresponsive to oxytocin to day 14 . However, by day 15, oxytocin stimulated endometrial turnover of inositol phosphate in vitro in these ewes, suggesting that onset of the luteolytic mechanism was delayed by 1-2 days.

Ewes that received progesterone up to day 15 and oCSP treatment did not exhibit increased PGFM in response to oxytocin from day 11 to 14 and remained unresponsive to oxytocin on day 15 (turnover of inositol phosphate). In cyclic ewes, endometrial responsiveness to oxytocin develops between days 12 and 16 (Mirando et al., 1990; Raw et al., 1990), and the mean interval from oestrus to first pulse of $\mathrm{PGF}_{2 \alpha}$ is 13.6 days (Zarco et al., 1988). Those results are in close agreement with the present results for ewes that received progesterone up to day 10 and SP. Pregnancy or injection of oCSP on days 12-14 blocks oxytocin-induced turnover of inositol phosphate measured in vitro on days 15 or 16, respectively (Mirando et al., 1990); and uterine production of $\mathrm{PGF}_{2 \alpha}$ in response to oxytocin in vivo is diminished by intrauterine injection of oTP-1 (Vallet et al., 1988b).

In the present study, development of the luteolytic mechanism was monitored as oxytocininduced endometrial production of $\mathrm{PGF}_{2 a}$ on days 11-14 and turnover of inositol phosphate on day 15 . These results indicate that endometrial responsiveness to oxytocin developed between days 13 and 14 in SP-treated and between days 12 and 13 in oCSP-treated ewes when plasma progesterone concentrations were declining. Enhanced responsiveness to oxytocin after treatment with purified oTP-1 was demonstrated in vitro with endometrium from ovariectomized ewes, and the response was dependent upon the ovariectomized ewes being pretreated with progesterone (Vallet \& Bazer, 1989). In addition, oTP-1 was shown to increase endometrial production of PGF Phen $_{2}$ when day 15 cyclic endometrium was treated in vitro with oTP-1 (Vallet \& Bazer, 1989). 
The reason for the apparent delay of 1-2 days in development of endometrial responsiveness to oxytocin in ewes receiving intrauterine injections of SP and progesterone to day 15 is unclear. Hixon \& Flint (1987) demonstrated that the luteolytic mechanism developed, in response to exogenous oestradiol, over 2-3 days, from a point of basal numbers of oxytocin receptors to coupling the oxytocin receptor to pulsatile secretion of prostaglandin. The present data showed maximal oxytocin-induced turnover of inositol phosphate and oxytocin-induced PGFM on day 13 in ewes in which progesterone was withdrawn from day 10 , suggesting that formation of oxytocin receptor occurred soon after progesterone concentrations began to decline. In SP-treated ewes receiving progesterone up to day 15 , oxytocin did not stimulate PGFM on day 14 but stimulated turnover of inositol phosphate on day 15, suggesting that oxytocin receptor formation was initiated on day 14. Perhaps the absence of follicular oestrogen or oxytocin, or of both, from a corpus luteum altered the timing of these events. Ovariectomized ewes treated with progesterone to mimic the cyclic variation of this steroid were responsive to oxytocin (plasma PGFM) on day 15, but not on days 5 or 10 of the cycle. Oestrogen treatment potentiated this effect (Homanics \& Silvia, 1988). In the present study, using ovariectomized progesterone-treated ewes, plasma PGFM and endometrial turnover of inositol phosphate in response to oxytocin developed in the absence of follicular oestrogen or oxytocin from a corpus luteum. Previous reports also showed that oestrogen may not be necessary for initiating the luteolytic mechanism (Homanics \& Silvia, 1988; Vallet \& Bazar, 1989; Vallet et al., 1990). However, numerous reports suggest that oestradiol is necessary for completion of luteolysis (Karsch et al., 1970; Baird et al., 1976; Flint \& Sheldrick, 1986; Sheldrick \& Flint 1990), perhaps by increasing the number of endometrial oxytocin receptors (Hixon \& Flint, 1987) or by affecting coupling of the oxytocin receptor to its phosphatidyl inositol second-messenger system (Vallet et al., 1990).

In the present study, basal concentrations of PGFM in plasma were high in ewes receiving oCSP and this effect was not dependent on progesterone treatment. This is consistent with previous reports (Lacroix \& Kann, 1983; Fincher et al., 1986; Vallet \& Bazer, 1989) that basal production of uterine PGF is raised during early pregnancy. Interestingly, the greatest rise in basal PGFM was evident on day 12 of the cycle, before the endometrium developed oxytocin-induced PGF secretion, suggesting that this may be an event mediated by oCSP, rather than oxytocin. The potential consequences of an oCSP-induced increase in basal PGF production include downregulation of PGF receptors on the corpus luteum, partial depletion of luteal oxytocin before endometrial oxytocin receptors are synthesized or depletion of endometrial phospholipid stores and thus a reduced PGF signal during maternal recognition of pregnancy. The mechanism responsible for raised basal PGFM in pregnant or oCSP-treated ewes was not examined. Establishment of an interferonmediated antiviral state of mouse L-cells in culture has been demonstrated to involve activation of fatty acid cyclooxygenase and thus PGF production (Pottathil et al., 1980). However, the induction of an antiviral state in Madin Darby bovine kidney cells by oTP-1 occurs in the presence of indomethacin, suggesting that products of the cyclooxygenase pathway (i.e. PGF) may not play a primary role in this response (M. A. Mirando \& F. W. Bazer, unpublished observations).

Results from this study are consistent with the hypothesis that the endometrium of ewes exhibits a progesterone-dependent block to the luteolytic effects of oestradiol or oxytocin during dioestrus (McCracken et al., 1984). Ewes receiving progesterone up to day 15 and SP exhibited oxytocin-induced endometrial turnover of inositol phosphate by day 15 , which was absent in the oCSP-treated ewes. The uterine luteolytic mechanism developed in the presence of high plasma progesterone concentrations and suggests that chronic progesterone may result in 'downregulation' of the progesterone receptor (Evans \& Leavitt, 1980; Leavitt et al., 1985). In support of this hypothesis, preliminary results indicate that intrauterine injection of oCSP from day 12 to day 14 in ovariectomized, progesterone-treated ewes results in an increase of about $40 \%$ in endometrial progesterone receptors when compared with SP infused ewes (M. A. Mirando, R. J. Moffatt, T. L. Ott \& F. W. Bazer, unpublished observations). A limited amount of data in cattle (Meyer et al., 1988 ) and pigs (Deaver \& Guthrie, 1980) has demonstrated that the rapid decline in numbers of 
progesterone receptors, which occurs as animals approach oestrus, does not occur during a similar stage of pregnancy. These results suggest that conceptus-mediated support (stabilization or upregulation) of endometrial progesterone receptors may be a common mechanism involved in maternal recognition of pregnancy in these three species.

Results from this study indicate that oCSP requires the presence of progesterone to inhibit oxytocin-induced production of $\mathrm{PGF}_{2 \alpha}$ and endometrial turnover of inositol phosphate in ovariectomized ewes. Intrauterine injection with oCSP results in raised basal concentrations of PGFM on days 12 and 13 and an earlier onset of oxytocin-induced production of PGF $_{2 \alpha}$ than SPtreated control ewes. The mechanism responsible for the interaction between progesterone and conceptus secretory proteins that allows for maternal recognition of pregnancy in ewes remains to be defined.

This paper is published as University of Florida Agricultural Experiment Station Journal Series No. R-01269 and the research was supported by NIH Grant HD10436. We thank F. Fliss for assistance with assays and R. D. Geisert for critical review of this manuscript.

\section{References}

Baird, D.T., Land, R.B., Scaramuzzi, R.J. \& Wheeler, A.G. (1976) Endocrine changes associated with luteal regression in the ewe: the secretion of ovarian oestradiol, progesterone and androstenedione and uterine prostaglandin $F_{2} \alpha$ throughout the oestrous cycle. Journal of Endocrinology 69, 275-286.

Bazer, F.W., Vallet, J.L., Roberts, R.M., Sharp, D.C. \& Thatcher, W.W. (1986) Role of conceptus secretory products in establishment of pregnancy. Journal of Reproduction and Fertility 76, 841-850.

Bazer, F.W., Vallet, J.L., Harney, J.P., Gross, T.S. \& Thatcher, W.W. (1989) Comparative aspects of maternal recognition of pregnancy between sheep and pigs. Journal of Reproduction and Fertility Supplement 37, 85-89.

Bazer, F.W., Thatcher, W.W., Hansen, P.J., Mirando, M.A., Ott, T.L. \& Plante, C. (1991) Physiological mechanisms of pregnancy recognition in ruminants. Journal of Reproduction and Fertility Supplement 43, $39-47$.

Deaver, D.R. \& Guthrie, H.D. (1980) Cytoplasmic estrogen receptor, estradiol and progesterone concentrations in endometrium of nonpregnant and pregnant pigs. Biology of Reproduction 23, 72-77.

Ellinwood, W.E., Nett, T.M. \& Niswender, G.D. (1979) Maintenance of the corpus luteum of early pregnancy in the ewe. II. Prostaglandin secretion by the endometrium in vitro and in vivo. Biology of Reproduction 21, 845-856.

Evans, R.W. \& Leavitt, W.W. (1980) Progesterone inhibition of uterine nuclear estrogen receptor: dependence on RNA and protein synthesis. Proceedings of the National Academy of Sciences USA 77, 5856-5860.

Fairclough, R.J., Smith, J.F. \& McGowan, L.T. (1981) Prolongation of the oestrous cycle in cows and ewes after passive immunization with PGF antibodies. Journal of Reproduction and Fertility 62, 213-219.

Fincher, K.B., Bazer, F.W., Hansen, P.J., Thatcher, W.W. \& Roberts, R.M. (1986) Proteins secreted by the sheep conceptus suppress induction of uterine prostaglandin $F-2 \alpha$ release by oestradiol and oxytocin. Journal of Reproduction and Fertility 76, $425-433$.

Flint, A.P.F. \& Sheldrick, E.L. (1986) Ovarian oxytocin and the maternal recognition of pregnancy. Journal of Reproduction and Fertility 76, 831-839.

Flint, A.P.F., Leat, W.M.F., Sheldrick, E.L. \& Stewart, H.J. (1986) Stimulation of phosphoinositide hydrolysis by oxytocin and the mechanism by which oxytocin controls prostaglandin synthesis in the ovine endometrium. Biochemical Journal 237, 797-805.

Godkin, J.D., Bazer, F.W., Moffatt, R.J., Sessions, F. \& Roberts, R.M. (1982) Purification and properties of a major, low molecular weight protein released by the trophoblast of sheep blastocysts at day 13-21. Journal of Reproduction and Fertility 65, 141-150.

Godkin, J.D., Bazer, F.W., Thatcher, W.W. \& Roberts, R.M. (1984) Proteins released by cultured day 1516 conceptuses prolong luteal maintenance when introduced into the uterine lumen of cyclic ewes. Journal of Reproduction and Fertility 71, 57-64.

Henderson, K.M., Scaramuzzi, R.J. \& Baird, D.T. (1977) Simultaneous infusion of prostaglandin $E_{2}$ antagonizes the luteolytic action of prostaglandin $\mathrm{F}_{2} \alpha$ in vivo. Endocrinology 72, 379-383.

Hixon, J.E. \& Flint, A.P.F. (1987) Effects of a luteolytic dose of oestradiol benzoate on uterine oxytocin receptor concentrations, phosphoinositide turnover and prostaglandin $\mathrm{F}_{2} \alpha$ secretion in sheep. Journal of Reproduction and Fertility 79, 457-467.

Homanics, G.E. \& Silvia, W.J. (1988) Effects of progesterone and estradiol-17 $\beta$ on uterine secretion of prostaglandin $\mathrm{F}_{2} \alpha$ in response to oxytocin in ovariectomized ewes. Biology of Reproduction 38, 804-811.

Hooper, S.B., Watkins, W.B. \& Thorburn, G.D. (1986) Oxytocin, oxytocin-associated neurophysin, and prostaglandin $F_{2} \alpha$ concentrations in the uteroovarian vein of pregnant and nonpregnant sheep. Endocrinology 119, 2590-2597.

Imakawa, K., Anthony, R.V., Kazemi, M., Marotti, K.R., Polites, H.G. \& Roberts, R.M. (1987) Interferon-like 
sequence of ovine trophoblast protein secreted by embryonic trophectoderm. Nature 330, 377-379.

Karsch, F.J., Noveroske, W.J., Roche, J.F., Norton, H.W. \& Nalbandov, A.V. (1970) Maintenance of ovine corpora lutea in the absence of ovarian follicles. Endocrinology 87, 1228-1236.

Lacroix, M.C. \& Kann, G. (1983) Discriminating analysis of in vitro prostaglandin release by myometrial and luminal sides of the ewe endometrium. Prostaglandins 25, 853-869.

Leavitt, W.W., Okulicz, C.C., McCracken, J.A., Schramm, W. \& Robidoux, W.F., Jr (1985) Rapid recovery of nuclear estrogen receptor and oxytocin receptor in the ovine uterus following progesterone withdrawal. Journal of Steroid Biochemistry 22, $687-691$.

Lowry, O.H., Rosebrough, N.J., Farr, A.L. \& Randal, R.J. (1951) Protein measurement with the folin phenol reagent. Journal of Biological Chemistry 193, 265-275.

McCracken, J.A., Carlson, J.C., Glew, M.E., Goding, J.R., Baird, D.T., Green, K. \& Samuelsson, B. (1972) Prostaglandin $\mathrm{F}_{2} \alpha$ identified as a luteolytic hormone in sheep. Nature New Biology 238, 129-134.

McCracken, J.A., Schramm, W. \& Okulicz, W.C. (1984) Hormone receptor control of pulsatile secretion of $\mathrm{PGF}_{2} \alpha$ from ovine uterus during luteolysis and its abrogation in early pregnancy. Animal Reproduction Science 7, 31-55.

Martal, J., Lacroix, M.C., Loudis, C., Saunier, M. \& Winterberger-Torres, S. (1979) Trophoblastin, an antiluteolytic protein present in early pregnancy in sheep. Journal of Reproduction and Fertility 56, 63-73.

Mapletoft, R.J., Lapin, D.R. \& Ginther, O.J. (1976) The ovarian artery as the final component of the luteotropic pathway between a gravid uterine horn and ovary in ewes. Biology of Reproduction 15, 414 421.

Meyer, H.H.D., Mittermeier, Th. \& Schams, D. (1988) Dynamics of oxytocin and progestin receptors in the bovine endometrium during the estrous cycle. Acta Endocrinologica (Copenhagen) 118, 96-104.

Mirando, M.A., Ott, T.L., Vallet, J.L., Davis, M.A. \& Bazer, F.W. (1990) Oxytocin-stimulated inositol phosphate turnover in endometrium of ewes is influenced by stage of the estrous cycle, pregnancy, and intrauterine infusion of ovine conceptus secretory proteins. Biology of Reproduction 42, 98-105.

Moor, R.M. \& Rowson, L.E.A. (1966a) The corpus luteum of the sheep: effect of the removal of embryos on luteal function. Journal of Endocrinology 34, 497-502.

Moor, R.M. \& Rowson, L.E.A. (1966b) The corpus luteum of the sheep: functional relationship between the embryo and the corpus luteum. Journal of Endocrinology 34, 233-239.

Okulicz, W.C., Evans, R.W. \& Leavitt, W.W. (1981) Progesterone regulation of the occupied form of nuclear estrogen receptor. Science 213, 1503-1505.

Pottathil, R., Chandrabose, K.A., Cuatrecasas, P. \& Lang, D.J. (1980) Establishment of the interferonmediated antiviral state: role of fatty acid cyclooxygenase. Proceedings of the National Academy of Sciences USA 77(9), 5437-5440.
Pratt, B.R., Butcher, R.L. \& Inskeep, E.K. (1977) Antiluteolytic effect of the conceptus and of $\mathrm{PGE}_{2}$ in ewes. Journal of Animal Science 45, 784-791.

Raw, R.E., Hayes, S.H. \& Silvia, W.J. (1990) Development of oxytocin-induced secretion of prostaglandin $\mathrm{F}_{2} \alpha$ during the estrous cycle and early pregnancy in ewes. Biology of Reproduction 42, (Supplement 1), 172.

Rhodes, L. \& Nathanielsz, P.W. (1990) Myometrial activity and plasma progesterone and oxytocin concentrations in cycling and early-pregnant ewes. Biology of Reproduction 42, 834-841.

Roberts, J.S., McCracken, J.A., Gavagan, J.E. \& Soloff, M.S. (1976) Oxytocin-stimulated release of prostaglandin $\mathrm{F}_{2} \alpha$ from ovine endometrium in vitro: correlation with estrous cycle and oxytocin-receptor binding. Endocrinology 99, 1107-1114.

SAS Institute (1982) Statistical Analysis System. SAS Circle, Cary, NC, USA.

Scaramuzzi, R.J. \& Baird, D.T. (1976) The oestrous cycle after active immunization against prostaglandin $\mathrm{F}_{2} \alpha$. Journal of Reproduction and Fertility 46, 39-47.

Sheldrick, E.L. \& Flint, A.P.F. (1985) Endocrine control of uterine oxytocin receptors in the ewe. Journal of Endocrinology 106, 249-258.

Sheldrick, E.L. \& Flint, A.P.F. (1990) Effect of continuous infusion of oxytocin on prostaglandin $F_{2} \alpha$ secretion and luteolysis in the cyclic ewe. Reproduction Fertility and Development 2, 89-99.

Silvia, W.J., Ottobre, J.S. \& Inskeep, E.K. (1984) Concentrations of prostaglandins $E_{2}, F_{2} \alpha$ and 6keto-prostaglandin $F_{1} \alpha$ in the utero-ovarian venous plasma of nonpregnant and early pregnant ewes. Biology of Reproduction 30, 936-944.

Snedecor, G.W. \& Cochran, W.G. (1980) Statistical Methods. Ames IA: Iowa State University Press.

Stewart, H.J., McCann, S.H.E., Baker, P.J., Lee, K.E., Lamming, G.E. \& Flint, A.P.F. (1987) Interferon sequence homology and receptor binding activity of ovine trophoblast antiluteolytic protein. Journal of Endocrinology 115, R13-R15.

Thorburn, G.D., Cox, R.I., Currie, W.B., Restall, B.J. \& Schneider, W. (1972) Prostaglandin F concentration in the utero-ovarian venous plasma of the ewe during the oestrous cycle. Journal of Endocrinology 53, 525-526.

Vallet, J.L. \& Bazer, F.W. (1989) Effect of ovine trophoblast protein-1, oestrogen and progesterone on oxytocin-induced phosphatidylinositol turnover in sheep. Journal of Reproduction and Fertility 87, 755-761.

Vallet, J.L., Bazer, F.W., Ashworth, C.J., Johnson, H.M. \& Pontzer, C.H. (1988a) Development of a radioimmunoassay for ovine trophoblast protein-1, the antiluteolytic protein from the sheep conceptus. Journal of Endocrinology 117, R5-R8.

Vallet, J.L., Bazer, F.W., Fliss, M.F.V. \& Thatcher, W.W. (1988b) Effect of ovine conceptus secretory proteins and purified ovine trophoblast protein-1 on interoestrous interval and plasma concentrations of prostaglandins F-2 $\alpha$ and E2 and of 13, 14-dihydro-15keto prostaglandin F- $2 \alpha$ in cyclic ewes. Journal of Reproduction and Fertility 84, 493-504. 
Vallet, J.L., Lamming, G.E. \& Batten, M. (1990) Control of endometrial oxytocin receptor and uterine response to oxytocin by progesterone and estradiol in the ewe. Journal of Reproduction and Fertility 90, $625-634$.
Zarco, L., Stabenfeldt, G.H., Quirke, J.F., Kindahl, H. \& Bradford, G.E. (1988) Release of prostaglandin F-2 $\alpha$ and the timing of events associated with luteolysis in ewes with oestrous cycles of different lengths. Journal of Reproduction and Fertility 83, 517-526.

Received 8 January 1991 